Uniwersytet im. A. Mickiewicza w Poznaniu

Wydział Neofilologii

Instytut Filologii Rosyjskiej i Ukraińskiej

tel.: +48618293576

e-mail: matjaw@amu.edu.pl

ORCID ID: https://orcid.org/0000-0002-4400-5546

\title{
Размытость досуга и службы \\ в рамках тоталитарного строя. \\ О Дне опричника Владимира Сорокина
}

Ключевые слова: Владимир Сорокин, Джорджо Агамбен, тоталитаризм, интертекстуальность, современная русская литература

С точки зрения настоящего времени, т. е. конца второго десятилетия XXI века, предыдущее столетие может казаться переломным моментом в истории человечества как в контексте его преуспевания и доминирования над природой благодаря немыслимому цивилизационному, технологическому и прежде всего научному прогрессу, так и в свете предельной реификации (овеществления) человеческой жизни в рамках тоталитарной власти, достигшей не наблюдаемых раньше масштабов. Эта бифуркация, своеобразное двойное направление усилий человеческого ума, несомненно может казаться нелепым и парадоксальным с одной стороны, человек начинает лечить смертельные раньше болезни, понимать квантовую природу реальности, летать в космос и общаться с помощью глобальной сети, с другой - жертвует собой и другими во имя тотальной идеологии, решается удалить определенные этнические группы, следуя выдуманным самим собою квазипринципам и любой ценой добивается полного контроля над жизнью других, перевоплощенных в массу. Вышеприведенные наблюдения уже десятки лет заставляют представителей разных гуманитарных наук задумываться над причинами, следствиями и сутью этой многовекторности. 
В центре наших размышлений последующих в нынешней статье стоит художественная литература, однако, опираются они также на философию и психологию, которые в состоянии обогатить интерпретацию релевантной терминологией и идейным фоном.

В контексте попытки прочтения выбранного произведения (День опричника) одного из выдающихся представителей русской словесности последних лет - Владимира Сорокина - в ключе воздействия тоталитарного строя на индивидуальное сознание несомненно важными могут оказаться идеи Джорджо Агамбена. Итальянский мыслитель, стараясь разъяснить феномен немецких концлагерей и ужас Холокоста, определяет воздействие власти на личную сферу жизни человека и разрабатывает понятие «чрезвычайное положение» (Агамбен 2012, 50-52). Агамбен очень интересным образом ссылается на размышления Аристотеля, создавая биополитическую доктрину человеческой жизни (Коzak 2009, Jaworski 2012). Итак, наше бытие состоит из двух обычно не соприкасающихся частей - bios и zôe, которые относятся к его социальной и биологической сторонам. Общественная жизнь человека непременно политизированна, так как обусловливается законом и властью, в то время как естественное бытие регулируется лишь природой и самим индивидуумом. Следовательно, zое̂ оказывается сферой вне политики, домом личностного бытия (oikos), в котором закон, действующий на уровне коллектива (polis), не находит применения (Jaworski 2012, 30). Тоталитаризм, однако, опирается на своеобразное (якобы временное) приостановление обычной организации общества. Ввиду нередко потенциальных или выдуманных причин создается обстановка, (ложно ведь) нуждающаяся в предприятии экстраординарных мер - агамбеновское чрезвычайное положение, в котором институт государства решается расширить свои прерогативы и вторгнуться в личную жизнь своих граждан. Агамбен определяет эту ситуацию с помощью термина исключение: «К парадигме «пограничной ситуации» и «экстремальных условий» в наше время часто обращаются как философы, так и теологи. Эта парадигма выполняет ту же функцию, что и чрезвычайное положение у некоторых теоретиков права. Подобно тому, как чрезвычайное положение позволяет обосновать и определить нормальный правопорядок, так лишь в контексте предельной ситуации - на самом деле она является разновидностью чрезвычайного положения - возможно судить и принимать решения о нормальном положении дел. Говоря словами Кьеркегора, «Исключение объясняет правило и само себя. Если вы хотите корректно исследовать правило, вам необходимо обратиться к исключению»» (Агамбен 2012, 51-52). Как ни странно, в свете закона 
любые действия власти во время чрезвычайного положения становятся легитимными. Итак, для создания машины массовой гибели стоило лишь найти подходящее ислкючение, которое давало санкцию на приостановление даже права человека на жизнь ${ }^{1}$.

Вышеприведенные идеи Агамбена почти прямым образом комментируют реальность выбранного нами произведения Сорокина - Дня опричника (2006). Многие критики замечают некую регрессивно-прогрессивную эклектичность историзма русского писателя, который создает в данном тексте мир отсталости, которому отнюдь не чужды новейшие технологические достижения ${ }^{2}$. Сочетание архаичности и футурологии, наблюдение за прошлым и созидание образа будущего, однако не явялются у Сорокина лишь художественным приемом или авторской шуткой над настоящим временем. По-нашему, автор Манараги строит действительность Нового Средневековья наподобие постмодернистского коллажа, мозаичность которого опирается на глубокое понимание невозможности понять случившееся. Писатель может лишь только использовать прошлое (и настоящее) в качестве интертекста (Кристева 2000, 427-457), который воспроизводится (иногда) как прямая цитата ${ }^{3}$.

Такое положение имплицирует сходство тоталитарного строя России в Дне опричника с организацией государственной машины Третьего Рейха и Советского Союза. В последующих размышлениях попытаемся найти параллели между историческим и художественным (т. е. антиутопическим, антиисторическим) образами отношений на линии власть - гражданин.

1 Здесь стоит упомянуть трудности израильской юридической системы обсудить преступления Адольфа Эйхмана. Ср. «дело построено прокурором на страданиях евреев, а не на деяниях Эйхмана» (Арендт 2008, 18); «если вдруг возникает преступление, которое ранее было не известно, например геноцид, правосудие должно вершиться в соответствии с новым законом; в случае Нюрнберга этим новым законом был Устав (Лондонское соглашение 1945 года), в случае Израиля - Закон от 1950 года. Вопрос не в том, имеют ли эти законы обратную силу, которую, конечно, они должны были иметь, а в другом: были ли они адекватны, то есть применимы только лишь к преступлениям, ранее не известным» (Арендт 2008, 379-380).

2 См. например Б. Ланин, Творчество Владимира Сорокина в современных исследованиях, «Comparative Studies on Regional Powers» 2010, № 5, с. 43-49; Н. Невярович, Художественнье конструкиии футурологического гротеска в антиутопии В. Сорокина "День опричника", http://ekhsuir.kspu.edu/xmlui/handle/123456789/2294 [11.02.2020]; Т. Юрченко, «Все мои книги - это отношение только с текстом»: o творчестве Владимира Сорокина, «Социальные и гуманитарные науки. Отечественная и зарубежная литература. Сер. 7, Литературоведение: Реферативный журнал» 2019, с. $162-169$.

3 Ср. «Внетекстовой реальности вообще не существует» (Деррида 2000, 313). 
Повествование в Дне опричника ведется от высоко поставленного представителя власти, опричника Комяги, который рисует картину будничного дня на своей службе. Здесь Сорокин, несомненно, отсылает читателя к одному из важнейших текстов мировой литературы XX века, разоблачающей ужасные последствия тоталитарной организации государства - Одному дню Ивана Денисовича Александра Солженицына. Однако стоит здесь отметить качественную разницу между ужасом ГУЛАГа, исторически случившегося и прожитого самим автором повести, и ужасом фиктивной системы, построенной на основе амплифицированной идеи защиты России от внешнего (вражеского) воздействия и ее соответственной изоляции 4 . Следует также поставить акцент на позицию рассказчика в тексте Сорокина - в отличие от повествования Одного дня Ивана Денисовича рассказ ведется от имени представителя репрессивной системы, моральная пустота которого вызывает его равнодушие к страданию не защищаемых своим общественным статусом граждан.

Интересно, что большинство интерпретаторов упускает само начало повести Сорокина, в котором рассказчик описывает часто снившийся ему зловещий сон:

Сон все тот же: иду по полю бескрайнему, русскому, за горизонт уходящему, вижу белого коня впереди, иду к нему, чую, что конь этот особый, всем коням конь, красавец, ведун, быстроног; поспешаю, а догнать не могу, убыстряю шаг, кричу, зову, понимаю вдруг, что в том коне - вся жизнь, вся судьба моя, вся удача, что нужен он мне как воздух, бегу, бегу, бегу за ним, а он все так же неспешно удаляется, ничего и никого не замечая, навсегда уходит, уходит от меня, уходит навеки, уходит бесповоротно, уходит, уходит, уходит... (Сорокин 2017, 7).

Антагонистическая пара - заглавный день и открывающий произведение сон - не случайна. Писатель здесь словно ведет игру с чи-

$4 \mathrm{~K}$ тому же здесь Сорокин возможно иронически разыгрывает поздние взгляды Солженицына на место России в современном мире и историческом процессе. Стоит здесь привести цитату из отзыва Андрея Сахарова, написанного по поводу одного из резких выступлений бывшего зэка: «В частности, бросается в глаза, что Солженицын особо выделяет страдания и жертвы именно русского народа. Конечно, право каждого писать и заботиться о том, что он лучше знает, что волнует его более лично, более конкретно. Но ведь все мы знаем, что ужасы гражданской войны, раскулачивания, голода, террора, Отечественной войны, неслыханных в истории антинародных жестоких репрессий миллионов вернувшихся из плена, преследования верующих, что все это в совершенно равной мере коснулось и русских и нерусских подданных советской державы». А. Сахаров, О письме Александра Солженицына «Вождям Советского Союза», http://www.sakharov-archive.ru/Raboty/Rabot_30.html [24.08.2020]. 
тателем, ожидающим злободневное описание занятий опричника (по аналогии к тексту Солженицына). K тому же уже с самого начала узнаем, что служба Комяги не оставляет никакого пространства для его личного развития, для его свободного времени. Даже сон, являющийся ведь очень интимным моментом в жизни любого человека, переполнен идеологическим пафосом (как на уровне языка описания употребление книжной архаичной лексики, поэтически звучащих кратких форм прилагательного, инверсии, так и в символическом плане белый конь, бескрайнее русское поле), который в данном случае используется для определения индивидуальньх переживаний и страстей героя. Итак, сон, традиционно принадлежащий к сфере zô, становится объектом вторжения власти (Ланин 2010, 47) (политической силы bios). Таким образом oikos почти незаметно превращается в polis, т. е. государство (как административная и символическая система) заменяет родной и естественный дом.

В данном ракурсе очередным важным моментом повествования оказывается также целеустремленное смешивание личной и профессиональной жизней героя. Выполняя свои обязанности, Комяга часто подчеркивает испытываемое им физиологическое удовольствие, которое не вписывается в так тщательно создаваемый им пафосный образ службы опричников. Стоит здесь привести два следующих примера:

Сладко! Как живой розовый поросеночек на вертеле раскаленном, вздрагивает и взвизгивает вдовица. Впиваюсь я зубами в ступню ее. Визжит она и бьется на столе. А я обстоятельно и неуклонно сочное дело вершу (Сорокин 2017, 73);

Сладки, ох и сладки эти удары! (Сорокин 2017, 198).

Рассказчик часто сам путает работу с досугом, очевидно относясь к своей жизни как к беспрестанному труду на благо родины. Например, скандальная сцена совокупления опричников, последующего за совместной трапезой и принятием наркотических средств, полностью опирается на физиологию, которая, однако, лишается своего индивидуального характера, так как интимное сближение персонажей становится коллективным актом. K тому же стоит отметить упорство рассказчика при назывании развлечения трудом, и наоборот. Описывая отдых опричнины в бане, Комяга говорит: «Теперь - помолчать время. Напряглись руки мускулистые, засопели ноздри молодецкие, закряхтели опричники. Сладкой работы время пришло. Окучиваем друг друга. Колышется вода вокруг нас, волнами ходит, из купели выплескивается. И вот уж подступило долгожданное» (Сорокин 2017, 214). 
Данный прием - смешивание службы и досуга, а также сопровождающая его смена личного коллективным кажутся доминантой в анализируемой нами повести. Очередным интересным примером здесь оказывается даже более неоднозначная сцена - наркотический сеанс, во время которого выбранные «старшие» опричники употребляют запрещенный законом наркотик - золотые рыбки удивляет не только сюжетом - видения опричников напоминают сцены из компьютерной игры, в которой цель управляемого ими персонажа убивать многочисленных врагов, в большинстве невинных и невооруженных. В данном случае, однако, эти враги совпадают с номинальными врагами Новой Руси - американцами. K тому же вся процедура имеет групповой характер, так как золотые рыбки применяются по строго определенному порядку, напоминающему племенной обряд. Сам кайф свободы также достигается коллективно, что замечает и сам рассказчик: «Рыбки - коллективное дело, в одиночку их пользовать дураком быть» (Сорокин 2017, 107).

Заинтересованный читатель здесь мог бы также задаться следующим вопросом - почему в мире произведения опричникам вверена такая необъемная власть, которая дает им право безнаказанно убивать, изнасиловать, грабить, употреблять запрещенные для других наркотики, зарабатывать на чужой беде и т. д.? Оказывается, что юридическая система Новой Руси, похоже на знакомые нам из уроков истории тоталитаризмы XX века, опирается на мнимую временность и агамбеновское чрезвычайное положение: «Супротивных много, это верно. Как только восстала Россия из пепла Серого, как только осознала себя, как только шестнадцать лет назад заложил Государев батюшка Николай Платонович первый камень в фундамент Западной стены, как только стали мы отгораживаться от чуждого извне, от бесовского изнутри - так и полезли супротивные из всех щелей, аки сколопендрие зловредное. Истинно - великая идея порождает и великое сопротивление ей [курсив - М. Я.]. Всегда были враги у государства нашего, внешние и внутренние, но никогда так яростно не обострялась борьба с ними, как в период Возрождения Святой Руси» (Сорокин 2017, 41-42). Можем полагать, что террор опричнины, являвшись основой абсолют-

5 Стоит здесь указать на символику такой формы наркотика, так как, несомненно, отсылает заинтересованного читателя к общеизвестной пушкинской сказке о золотой рыбке, исполняющей любые желания и в конечном счете наказывающей человеческую жадность. В данном контексте этот мотив можем считать даже отдаленным намеком на финал Сахарного Кремля, в котором Комяга гибнет. 
ной власти нового царя, в свете повести должен длиться пока в Руси имеются государственные враги. Однако и этот термин относителен - в финале Сахарного Кремля, второй части сорокинского диптиха об опричнине,врагом народа оказывается сам Комяга, ведь так тщательно и страстно выполняющий-переживающий свою службу-жизнь ${ }^{6}$.

В результате нашего контекстуального анализа выбранного произведения Владимира Сорокина несомненно можем заключить, что реальность Нового Средневековья с ее ужасающей отсталостью, поддерживаемой новейшими технологиями и бесконечным насилием государственного аппарата, построена наподобие тоталитарных систем прошлого. Важными здесь оказались размышления Джорджо Агамбена, особенно для раскрытия тотальной, т. е. захватывающей и интимно-физиологическую жизнь человека, власти. В таком мире исчезает, или точнее - размывается, различие между службой и досугом, трудом и отдыхом, долгом и удовольствием, а также, что даже важнее - сном и явью, вымышленным и настоящим.

\section{Литература}

Agamben G., Homo sacer. Čto ostaetsâ posle Osvencima: arhiv i svidetel', per. s ital'ânskogo, Moskva 2012. [Агамбен Дж., Homo sacer. Что остается после Освенцима: архив и свидетель, пер. с итальянского, Москва 2012.]

Arendt H., Banal'nost' zla. Ėjhman v Ierusalime, per. S. Kasmal'skogo i N. Rudnickoj, Moskva 2008. [Арендт Х., Банальность зла. Эйхман в Иерусалиме, пер. С. Касмальского и Н. Рудницкой, Москва 2008.]

Derrida J., O gramatologii, per. N. Avtonomovoj, Moskva 2000. [Деррида Ж., О граматологии, пер. Н. Автономовой, Москва 2000.]

Kristeva U., Bahtin, slovo, dialog i roman, per. G. Kosikova, [v:] Francuzskâ̂ semiotika: ot strukturalizma $k$ poststrukturalizmu, sostavitel' G. Kosikov, per. G. Kosikova, Moskva 2000, s. 427-457. [Кристева Ю., Бахтин, слово, диалог и роман, пер. Г. Косикова, [в:] Франиузская семиотика: от структурализма к постструктурализму, составитель Г. Косиков, пер. Г. Косикова, Москва 2000, с. 427-457.]

Lanin B., Tvorčestvo Vladimira Sorokina v sovremennyh issledovaniâh, «Comparative Studies on Regional Powers» 2010, № 5, s. 43-49. [Ланин Б., Творчество Владимира Сорокина в современных исследованиях, «Comparative Studies on Regional Powers» 2010, № 5, c. 43-49.]

6 И здесь несомненно можем обнаружить «прямую цитату» из истории Советского Союза и Третьего Рейха - соответственно сталинский террор 1937 года и Ночь длинных ножей 1934 года. 
Nevârovič N., Hudožestvennye konstrukcii futurologičeskogo groteska $v$ antiutopii V. Sorokina "Den' opričnika”, [Невярович Н., Художественные конструкиии Футурологического гротеска в антиутопии В. Сорокина “День опричника"], [online], http://ekhsuir.kspu.edu/xmlui/handle/123456 $789 / 2294$ [11.02.2020].

Saharov A., O pis'me Aleksandra Solženicyna «Voždâm Sovetskogo Soûza», [Caхаров А., O письме Александра Солженичына «Вождям Советского Союза»], [online], http://www.sakharov-archive.ru/Raboty/Rabot_30.html [24.08.2020].

Sorokin V., Den' opričnika, Moskva 2017. [Сорокин B., День опричника, Москва 2017.]

Ûrčenko T., «Vse moi knigi - èto otnošenie tol'ko s tekstom»: o tvorčestve Vladimira Sorokina, "Social'nye i gumanitarnye nauki. Otečestvennaâ i zarubežnaâ literatura. Ser. 7, Literaturovedenie: Referativnyj žurnal" 2019, s. 162-169. [Юрченко Т., «Все мои книги - это отношение только с текстом»: о творчестве Владимира Сорокина, "Социальные и гуманитарные науки. Отечественная и зарубежная литература. Сер. 7, Литературоведение: Реферативный журнал" 2019, с. 162-169.]

Jaworski M., Człowiek sprowadzony do obozu. Próba interpretacji twórczości Wartama Szałamowa w kontekście filozofii Georgio Agambena, [w:] Kultury wschodniostowiańskie - oblicza i dialog. Polska - Rosja - Ukraina, pod red. W. Popiel-Machnickiego, Poznań 2012, s. 29-32.

Kozak P., Teologia biopolityczna Giorgio Agambena, "Diametros" 2009, s. 96-113.

\section{AMBIGUITY OF SPARE TIME AND SERVICE WITHIN A TOTALITARIAN SYSTEM. ON DAY OF THE OPRICHNIK BY VLADIMIR SOROKIN}

ABSTRACT

Key words: Vladimir Sorokin, Giorgio Agamben, totalitarianism, intertextuality, contemporary Russian literature

The present paper aims at presenting the ambiguity of spare time and service in Vladimir Sorokin's Day of the Oprichnik in the context of the fictional totalitarian system of the New Middle Ages and the historical atrocity of the Nazi and Soviet history. The proposed interpretation has been based on Giorgio Agamben's reflections on the individual's status under the exceptional circumstances of an extremely oppressive regime. The analysis has led the author to conclude the imminent and omnipresent blurring and overlapping of the intimate and the public in Sorokin's book. Moreover, Day of the Oprichnik may be seen as a rich universe of intertextual references interweaving into a complex picture of a human being disappearing in the uniform crowd of state officers. 